\title{
FAKTOR PENENTU BRAND EQUITY DAN PENGARUHNYA PADA PURCHASE INTENTION
}

\author{
Evo Sampetua Hariandja ${ }^{1}$ \\ Universitas Pelita Harapan, Tangerang, Indonesia \\ evo.hariandja@uph.edu \\ Aurellia Adeline ${ }^{2}$ \\ Universitas Pelita Harapan, Tangerang, Indonesia \\ AA2051@student.uph.edu \\ Ferdinandus Eric ${ }^{3}$ \\ Universitas Pelita Harapan, Tangerang, Indonesia \\ s00000014718@student.uph.edu \\ Yossel Christopher ${ }^{4}$ \\ Universitas Pelita Harapan, Tangerang, Indonesia \\ YC1416@student.uph.edu \\ Diterima 17 Juli 2020 \\ Disetujui 31 Maret 2021
}

\begin{abstract}
This study aims to determine the effect of brand popularity on brand loyalty, brand awareness, perceived quality and brand reputation among Etude House Indonesia users. Other objective of this study are to the effect of brand loyalty, brand awareness, perceived quality and brand reputation on brand equity. The effect of brand equity on purchase intention To address the objectives of the study, a quantitative research design was implemented by distributing the questionaires to 360 Etude House Indonesia users and implementing the intruments that fulfilled the validity and reliability test requriements. The data were analyzed by SEM SmartPLS 3. The findings revealed that there was an effect of Brand popularity affects brand awareness, perceived quality, and brand reputation. Other results show that the counrry of brand origin affects brand loyalty, brand awareness and brand perceived quality. Also, Brand equity is determined by brand loyalty and brand reputation. While Brand equity has a significant effect on purchase intention. In addition, brand equity also impacts on purchase intention. However, in this study the relationship of brand popularity to brand loyalty, the effect of country of brand origin on brand reputation, the effect of brand awareness on brand equity and the effect of perceived quality on brand equity is not supported in hypothesis testing.
\end{abstract}

Keywords: Brand Popularity; Country of Brand Origin; Brand Loyalty, Brand Awareness; Perceived Quality; Brand Reputation; Brand Equity; Purchase Intention 


\section{PENDAHULUAN}

\subsection{Latar Belakang}

Kebutuhan konsumen saat ini selain untuk mencukupi kebutuhan utama seperti sandang, pangan, papan, ada pula kebutuhan sekunder dan tersier antara lain perawatan dan kecantikan. Sementara $64 \%$ pria menempatkan penampilan yang rupawan dalam 3 prioritas utama mereka, angka ini hanya 36\% bagi wanita (Yougov, 2017). Penampilan fisik sekarang ini sudah menjadi prioritas utama yang akhir akhir ini dianggap menjadi suatu kewajiban yang dipenuhi oleh wanita juga pria karena dapat memiliki keuntungan sosial (Kershaw, Newton, \& Williams, 2008)Hal tersebut yang menjadikan produk-produk kosmetik dan produk kecantikan gencar dicari oleh konsumen. Berbagai nama nama merek kecantin yang ditawarkan dari produsen dengan berbagai keunggulan produk mereka.

Kementerian Perindustrian Indonesia menargetkan pertumbuhan industri kosmetik pada tahun 2019 telah mencapai 9\%, pertumbuhan peningkatan ini menaik dari tahun lalu dari sekitar 7,3\%. Peningkatan ini didorong oleh adanya tren kebutuhan pada kecantikan dan perawatan tubuh. Kemenperin mencatat saat tahun 2017, industri kosmetik di Indonesia telah mencapai lebih dari 760 produsen. Dari angka tersebut, senilai 95\% industri kosmetika nasional ini berasal dari sektor industri kecil dan menengah (IKM). Kemudian di tahun 2017, nilai ekspor produk kosmetik nasional mencapai US\$ 516,99 juta, yang artinya naik hingga 16\% dibandingkan tahun sebelumnya hanya sebesar US\$ 470,30 juta (Ekarina, 2019).

Hal tersebut menjadikan persaingan antar produk kecantikan di Indonesia menjadi ketat dengan muncul macam macam produk kosmetik dari luar negeri yang masuk ke Indonesia serta masuk dalam persaingan produk kosmetik. Merek-merek kosmetik yang ada di Indonesia terdiri dari kosmetik lokal dan internasional. Merek kosmetik lokal antara lain: Viva Cosmetics, Sariayu, Caring Colours, Wardah, PAC, Inez Cosmetics, Make Over, Mineral Botanica, Emina dan BLP Beauty. Sedangkan merek kosmetik internasional dengan penjualan terbaik di Indonesia adalah Loreal (Perancis), Etude House (Korea Selatan), Revlon (Amerika Serikat), Urban Decay (Amerika Serikat), Mac (Canada), dan Clinique (Amerika Serikat). Dari tabel dibawah ini dapat disimpulkan bahwa kosmetik yang berasal dari Korea Selatan menempati urutan kedua, menandakan bahwa Korea Selatan menjadi salah satu negara yang dipercaya konsumen Indonesia mengenai kualitas produk yang dihasilkan, menjadikan produkproduk yang berasal dari Korea Selatan menjadi pertimbangan mereka, salah satunya adalah merk Etude House seperti ditujukkan dalam Tabel 1 dan Gambar 1 di bawah.

Tabel 1. Top Ten International Brands in Indonesia

\begin{tabular}{lll}
\hline & Brand & Country of Origin \\
\hline 1 & L'oreal & French \\
2 & Etude House & South Korea \\
3 & Revlon & United States \\
4 & Avon & United States \\
5 & Covergirl & United States \\
6 & Oriflame & Sweden \\
7 & Urban Decay & United States \\
8 & Maybelline New York & United States \\
9 & MAC & Canada \\
10 & Clinique & United States \\
\hline
\end{tabular}

Sumber: Clicktop 10,2013 


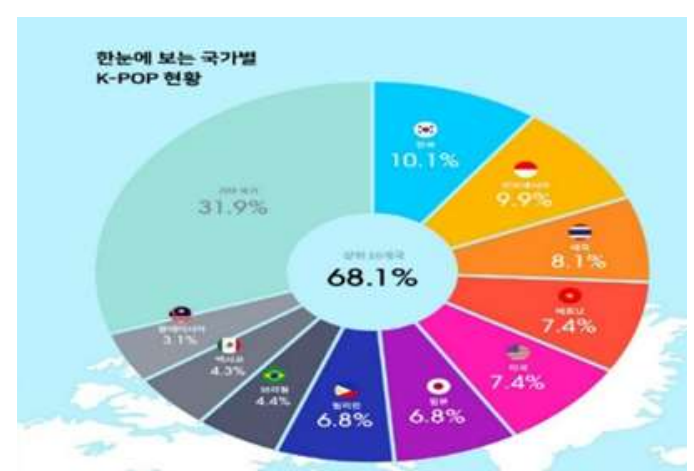

\section{Gambar 1. Data 10 negara dengan jumlah penggemar K-Pop terbesar berdasarkan penelitian data dari pandangan YouTube.}

Sumber: Koreaboo

Etude House merupakan pemain yang relatif baru di pasar Indonesia dibandingkan dengan merk yang berasal dari Korea lainnya (Devita \& Agustini, 2019). Etude House hadir pertama kali di Indonesia, tepatnya di Jakarta, pada tahun 2008. Kualitas yang baik, harga yang terjangkau, desain yang unik dan cantik, dan pilihan warna yang beragam mampu menarik perhatian para pecinta kosmetik di Indonesia. Hal ini didukung dengan demam Kpop atau Korean waves yang melanda Indonesia (Pumice, 2014) .

Jika dilihat dari gambar diatas Indonesia ada di posisi ke-2 yaitu senilai 9,9\% dari total penonton yang ada di YouTube. Kecintaan masyarakat Indonesia terhadap Korean Pop terus meningkat, karena semakin banyak artis dari korean Pop yang membuat negara Indonesia masuk kedalam list tujuan wisata mereka yang akan mereka singgahi. Ada pula, agensi bergengsi terbesar di Korea yaitu SM Entertainment yang telah bekerja sama dengan perusahaan media di Indonesia, yaitu Transmedia Corp. (TimWowkeren, 2019).

Munculnya istilah Korean waves dimulai dari beberapa drama televisi yang populer di Asia Timur, dan industri budaya lokal telah mengembangkan beberapa bentuk budaya termasuk musik populer, animasi, permainan digital, yang perlahan-lahan telah menembus pasar global. Adanya ledakan Korean waves di berbagai bidang, bagian ini berfokus pada negara asal Korean waves, yang merupakan pertumbuhan cepat budaya populer lokal di kancah global(Jin \& Yoon, 2017)

Menjadikan, hal tersebut muncul niat beli konsumen di Indonesia. Niat beli ialah keinginan konsumen untuk membeli produk tertentu dalam kondisi tertentu. Namun, baru-baru ini Otoritas Keamanan Obat dan Makanan Korea Selatan menemukan adanya logam berat berbahaya dalam jumlah berlebih pada kosmetik merk tertentu di Korea Selatan salah satunya adalah beberapa produk dari Etude House. Akibatnya kosmetik tersebut harus ditarik dari peredaran (Dessylistya, 2018).

Permasalahan tersebut tentu saja dapat mempengaruhi brand equity produk tersebut, karena konsumen sekarang ini biasanya menilai produk hanya dari merek saja, manajemen brand yang baik akan memberi arah kepada brand equity yang tinggi (Nigam \& Kaushik, 2011). Brand equity ialah kekuatan merek yang dapat menghasilkan nilai terhadap perusahaan juga dengan konsumen. Menurut penilaian perusahaan, brand equity membuat nilai lebih, aliran kas, dan target pasar yang lebih luas lagi. Sedangkan dari penilaian konsumen, brand equity bersingungan dengan hal yang baik dan jelas mengenai merek yang ada dipikirkan oleh konsumen (Valdo \& Subagio, 2017).

Berbagai penelitian tentang keterkaitan brand awareness, perceived quality dan brand loyalty terhadap purchase intention telah dilakukan. Brand awareness perlu ditanamkan kepada 
para konsumen, hal ini bertujuan untuk mendorong konsumen agar menjadikan merek produk tertentu sebagai pilihan utama. Konsumen tentu lebih berminat pada merek yang mereka persepsikan mempunyai kualitas bagus, sehingga dapat menjadikan konsumen menjadi loyal terhadap merk tertentu (Valdo \& Subagio, 2017).

Brand reputation yang baik juga perlu diterapkan karena mempengaruhi faktor niat beli calon konsumen. Dengan semakin banyaknya persaingan di bidang industri, tentu saja calon konsumen memiliki banyak pilihan untuk membeli kosmetik, yang menjadi perbandingan konsumen salah satunya yaitu brand reputation. Oleh karena itu, reputasi dari suatu merk merupakan salah satu faktor yang menentukan berhasil tidaknya produk kosmetik yang dijual. Penelitian yang dilakukan oleh (Tsou, Liu, \& Hsu, 2015), menjelaskan bahwa terdapat pengaruh brand reputation terhadap purchase intention. Reputasi adalah evaluasi keseluruhan sejauh mana suatu perusahaan secara substansial "baik" atau "buruk". Reputasi yang kuat meningkatkan kepercayaan konsumen terhadap produk dan layanan yang ditawarkan, sehingga menciptakan purchase intention. Ini menunjukkan bahwa perusahaan harus membangun reputasi positif. Di sisi lain, reputasi yang buruk dapat membahayakan penurunan niat beli konsumen.

Brand awareness, brand loyalty, brand reputation dan perceived quality dalam mengevaluasi produk juga dapat dilihat dari negara asal produk tersebut disebut sebagai "country of brand origin". Country of brand origin (COO) yang menggunakan penilaian konsumen menjadi salah satu sebagai strategi produsen dikalangan dunia. Penelitian yang dilakukan oleh (Srihartati \& Abdillah, 2018), mengatakan bahwa konsumen dalam mendeskripsikan suatu produk tidak hanya dari penampilan dan karakteristik produk saja. Negara asal tempat produksi produk menjadi salah satu hal pertimbangan konsumen dalam menilai suatu barang. Country of brand origin juga saling berkaitan terhadap brand equity, brand awareness menjadi salah satu komponen yang berkaitan.

Country of brand origin memiliki penilaian yang baik mengenai produk tertentu seperti, yang dilakukan oleh Etude House. Dimana tujuan Etude House ialah membuat wanita lebih percaya diri dengan cara membuat produk kosmetik yang atraktif dan dengan konseling yang ramah. Citra Korea sebagai negara asal Etude House mempunyai citra yang positif (Devita, 2019).

Disamping country of brand origin, brand popularity juga merupakan salah satu aspek yang sering dipakai para konsumen sebagai acuan untuk menciptakan brand equity. Produk dengan brand popularity yang lebih tinggi dapat memberikan peran penting untuk membuat konsumen memiliki brand awareness, brand loyalty, brand reputation dan perceived quality dibandingkan dengan produk yang memiliki brand popularity lebih rendah. Penelitian yang dilakukan oleh (Chang \& Chang, 2014)menunjukkan bahwa brand awareness memungkinkan konsumen untuk lebih mudah mengenali brand popularity yang tinggi. Merek yang memiliki popularitas yang tinggi dapat dengan mudah dipikirkan, serta mengungkapkan pengakuan merek yang lebih tinggi dan kesadaran konsumen.

Berdasarkan masalah tersebut, maka penelitian ini akan menganalisis efek brand popularity dan country of brand origin pada dimensi brand equity, brand reputation dan purchase intentions pada pengguna Etude House Indonesia. 


\subsection{Tinjauan Pustaka dan Pengembangan Hipotesis \\ 1.2.1 Brand popularity dan Brand loyalty}

Loyalitas konsumen dipandang sebagai kekuatan hubungan antara sikap relatif individu dan perlindungan berulang. Konsumen dapat menyukai brand yang memiliki brand personality yang lebih berbeda, dan dapat memungkinkan juga konsumen lebih mengenal brand yang mereka sukai. Konsumen mungkin dapat menggunakan brand dan produk sesuai dengan sifat kepribadian mereka sendiri (Farhat \& Mustafa, 2011). Membangun dan mempertahankan brand loyalty adalah salah satu tema utama penelitian bagi pemasar untuk waktu yang sangat lama (Erdoğmuş \& Çiçek, 2012). Lebih spesifik lagi, arti yang terkait dengan brand popularity memberi energi positif pada penilaian konsumen terhadap tingkat difusi atau popularitas suatu brand di masyarakat, yaitu jumlah orang yang membeli brand yang serupa. Brand popularity dapat dianggap sebagai salah satu faktor karena kepentingan suatu budaya (Filieri, Lin, D'Antone, \& Chatzopoulou, 2018).

Akibatnya, semakin banyak produk atau merek Etude House yang dipilih oleh konsumen, semakin menjadi populer di masyarakat. Dengan meningkatnya brand popularity, loyalitas yang melekat pada merek yang telah menjadi merek yang dipilih oleh anggota masyarakat juga meningkat. Brand loyalty merupakan ukuran kesetiaan seorang pelanggan pada sebuah merek. Terdapat dua pendekatan yang digunakan untuk memahami brand loyalty yang dalam literatur pemasaran. Pendekatan pertama dalam literatur pemasaran adalah pendekatan perilaku terhadap brand loyalty di mana para pendukung percaya bahwa pembelian konstan satu merek dari waktu ke waktu merupakan indikator loyalitas merek. Pendekatan kedua dalam literatur pemasaran adalah pendekatan kognitif terhadap loyalitas merek di mana para ahli berpendapat bahwa perilaku semata-mata tidak mencerminkan brand loyalty (Severi \& Ling, 2013).

Penelitian yang dilakukan oleh (Luan, Shan, Wang, \& Xiao, 2019) menunjukkan bahwa brand popularity membantu seseorang untuk memahami bagaimana konsumen memilih dan memproses informasi yang mudah diproses dan memahami produk serta membuat keputusan berdasarkan informasi tersebut di bawah berbagai keakraban produk dan kondisi ketersediaan informasi. Selain itu, penelitian yang dilakukan oleh Filieri et al., (2018), menemukan adanya pengaruh antara brand popularity dengan brand loyalty. Dengan demikian, mengikuti literatur ini kami berpendapat bahwa semakin tinggi brand popularity, semakin banyak konsumen memiliki brand loyalty itu. Dengan demikian, hipotesis yang diajukan adalah:

\section{H1a = Terdapat pengaruh brand popularity terhadap brand loyalty}

\subsubsection{Brand popularity dan Brand awareness}

Brand awareness yang tinggi biasanya memiliki nilai penarikan kembali merek tersebut ketika sering melihat merek tersebut(Liao, Wu, Widowati, \& Chen, 2012). Seiring peningkatan frekuensi penarikan merek, ada tingkat brand awareness yang lebih besar. Brand popularity memiliki brand awareness yang lebih luas dan fondasi emosional yang lebih kuat, sehingga sikap konsumen terhadap merek lebih kecil kemungkinannya untuk berubah (Fan, Chang, Zhang, \& Zhang, 2013). Penelitian yang dilakukan oleh (Gisbey, 2016) menjelaskan bahwa brand awareness bertindak sebagai sinyal kuat kualitas produk dan komitmen pemasok. Selain itu, brand awareness dapat menunjukkan keandalan yang telah lama ada, penerimaan yang luas dan prestise dari pihak perusahaan terkait. Konsumen dapat menggunakan brand awareness sebagai keputusan pembelian. Namun, mungkin ada hubungan antara brand awareness dan aspek lain yang dapat diamati dari perilaku konsumen dan merek. Ini menunjukkan bahwa tingkat brand awareness yang tinggi mungkin tidak diterjemahkan ke tingkat brand popularity yang tinggi. Di sisi lain, mungkin diharapkan bahwa tingkat brand popularity yang rendah 
dikaitkan dengan tingkat brand awareness yang rendah karena ada sejumlah kecil pengguna produk.

Penelitian yang dilakukan oleh (Hassan, Shabbir, Yaqub, \& Imran, 2016), menunjukkan bahwa brand popularity dapat menciptakan brand awareness di benak konsumen dan dapat memengaruhi kepuasan konsumen secara langsung atau tidak langsung. Penelitian yang sama juga dilakukan oleh (Filieri et al., 2018), menemukan bahwa terdapat pengaruh brand popularity dengan brand awareness. Dengan demikian, mengikuti literatur ini kami berpendapat bahwa semakin tinggi brand awareness, semakin banyak konsumen memiliki brand awareness merek itu. Maka dari itu, hipotesis yang diajukan adalah:

\section{$\mathrm{H1b}=$ Terdapat pengaruh brand popularity terhadap brand awareness}

\subsubsection{Brand popularity dan Perceived quality}

Brand popularity didefinisikan sebagai sejauh mana suatu merek dipilih dan dibeli oleh populasi umum. Brand popularity memiliki dampak positif pada perilaku konsumen (J.-H. Kim \& Min, 2016). Brand popularity mengacu pada keadaan suatu produk yang dibeli oleh sejumlah besar orang, dan dengan demikian diterima secara luas. Konsumen membentuk preferensi mereka untuk suatu produk yang dipromosikan dengan informasi popularitasnya, karena mereka dapat membangun persepsi tentang penilaian mereka dan keputusan pembelian berdasarkan popularitas relatif suatu produk (Lee, 2017). Penelitian yang dilakukan oleh (J. H. Kim \& Min, 2014), menemukan bahwa terdapat pengaruh brand popularity dengan perceived quality. Penelitian yang sama dilakukan oleh (Filieri et al., 2018), menemukan bahwa terdapat pengaruh brand popularity dengan perceived quality. Dengan demikian, mengikuti literatur ini kami berpendapat bahwa semakin tinggi brand popularity, semakin tinggi perceived quality produk itu. Maka dari itu, hipotesis yang diajukan adalah:

\section{H1c = Terdapat pengaruh brand popularity terhadap perceived quality.}

\subsubsection{Brand popularity dan Brand reputation}

Brand reputation dan brand popularity memainkan peran penting dalam mengarahkan konsumen untuk memilih apa yang akan dibeli. brand popularity telah didefinisikan sebagai sejauh mana merek banyak dicari dan dibeli oleh populasi umum (Kim, Moon, \& Iacobucci, 2019)Pernyataan brand popularity, juga disebut pernyataan norma sosial deskriptif, yang dapat didefinisikan sebagai pernyataan yang menyerukan penggunaan merek secara luas (Magnini, Karande, Singal, \& Kim, 2013). Sedangkan brand reputation, dari sudut pandang perusahaan, adalah konstruksi sentral yang panjang dalam pemasaran. Ini digunakan sebagai ukuran untuk melihat seberapa besar konsumen dipengaruhi oleh suatu merek. Pertama, merek adalah nama, istilah, tanda, simbol, desain, atau kombinasi dari semua hal ini, yang dimaksudkan untuk mengidentifikasi barang atau jasa dari satu penjual atau kelompok penjual dan untuk membedakan mereka dari pesaing mereka. Suatu produk dapat disalin oleh pesaing tetapi suatu merek selalu unik. Suatu produk dapat usang dengan cepat tetapi merek yang populer tidak lekang oleh waktu, terutama ketika memiliki reputasi yang kuat (Wang, Wu, \& Fu, 2010).

Penelitian yang dilakukan oleh (Filieri et al., 2018)menemukan bahwa terdapat pengaruh brand popularity dengan brand reputation. Dengan demikian, mengikuti literatur ini kami berpendapat bahwa semakin tinggi brand popularity, semakin tinggi brand reputation produk itu. Dengan demikian, hipotesis yang diajukan adalah:

\section{H1d = Terdapat pengaruh brand popularity terhadap brand reputation}




\subsubsection{Country of brand origin dan Brand loyalty}

Brand loyalty adalah konstruksi teoretis yang semakin lazim dalam literatur dan country of brand origin juga merupakan konsep penting bagi pemasar. Dampak yang diberikan oleh country of brand origin adalah sejauh mana evaluasi konsumen terhadap suatu produk dan responsnya didorong oleh country of brand origin produk tersebut (Bruwer \& Buller, 2013). Konsumen akan sering menggunakan kebutuhan intrinsik dan ekstrinsik yang disediakan oleh pemasar sebagai petunjuk tentang kualitas produk untuk membuat keputusan. Penggunaan ini akan bervariasi tergantung pada loyalitas konsumen atas produk tersebut, sedangkan country of brand origin memiliki peran penting sebagai kebutuhan ekstrinsik suatu kualitas produk (Bruwer \& Buller, 2013).

Oleh karena itu, dapat dikatakan bahwa Country of brand origin memiliki dampak positif pada brand loyalty. Misalnya, jika konsumen melihat negara dari mana merek berasal sebagai modern dan maju secara teknologi, mereka akan kurang enggan untuk beralih ke merek dari negara yang tidak unggul dalam kategori produk seperti itu sesuai dengan persepsi stereotip konsumen. Dengan demikian, konsumen akan terus membeli produk dan merek yang berasal dari negara yang mereka anggap lebih unggul dalam hal kemajuan teknologi (Filieri et al., 2018). Maka hipotesis yang diajukan adalah

\section{H2a = Terdapat pengaruh country of brand origin terhadap brand loyalty}

\subsubsection{Country of brand origin dan Brand awareness}

Saat ini, kesadaran konsumen yang menigkat untuk membeli merek yang sering mereka dengar dan memberi keuntungan bagi mereka yang menjalankan kegiatan bisnis dalam sektor ini. Saat konsumen ingin membeli produk, maka nama merek yang ada dibenak mereka pertama kali teringat ini menunjukkan produk tersebut memiliki brand awareness yang tinggi (Eliasari \& Sukaatmadja, 2017). Dalam studi ini kami berpendapat bahwa konsumen saat ini sangat memperhatikan setiap teknologi atau inovasi baru yang berasal dari negara-negara maju secara teknologi seperti Korea, yang mereka anggap memiliki persepsi positif. Konsumen muda semakin sadar akan merek kosmetik yang berasal dari negara Korea. Selain itu, banyak produsen kosmetik juga menawarkan berbagai produk kecantikan yang dapat meningkatkan pengetahuan konsumen tentang country of brand origin dan pada saat yang sama pengetahuan konsumen tentang merek-merek ini. Country of brand origin dapat menjadi pendorong penting minat terhadap merek, yang dapat meningkatkan daya ingat dan pengakuan merek (Filieri et al., 2018).

Penelitian yang dilakukan oleh (Filieri et al., 2018), menemukan bahwa terdapat pengaruh country of brand origin dengan brand awareness. Dengan demikian, mengikuti literatur ini kami berpendapat bahwa semakin tinggi country of brand origin, semakin banyak konsumen memiliki brand awareness merek itu. Dengan demikian, hipotesis yang diajukan adalah:

\section{$\mathrm{H} 2 \mathrm{~b}=$ Terdapat pengaruh country of brand origin terhadap brand awareness.}

\subsubsection{Country of brand origin dan Perceived quality}

Dampak dari country of brand origin telah diteliti sejak awal 1960-an dan fokus penelitian cenderung berkembang dari hanya verifikasi keberadaan efek kebangsaan produk ke penyelidikan beberapa faktor penentu yang akan mempengaruhi besarnya dampak (Costa, Carneiro, \& Goldszmidt, 2016). Perceived quality merupakan hal yang dirasakan konsumen pada merek atau produk yang tidak dapat dinilai secara objektif. Hasil penelitian yang dilakukan oleh (Dinata, Kumadji, \& Hidayat, 2015) menunjukkan bahwa country of brand origin memiliki pengaruh signifikan terhadap perceived quality kepada calon konsumen. Hal 
ini menunjukkan bahwa semakin seorang calon konsumen mempercayai citra suatu country of brand origin (country of brand origin) itu positif, maka tentu akan menciptakan perceived quality yang baik pula pada produk tersebut.

Sebagai contoh, konsumen Cina menyukai merek Barat karena mereka percaya bahwa Amerika memiliki standar kualitas yang tinggi. Persepsi ini disebabkan oleh seringnya masalah keamanan produk yang, bersama-sama dengan lemahnya pengawasan pemerintah, telah mendorong konsumen Cina menjauh dari produk dalam negeri tertentu (Filieri et al., 2018). Maka hipotesis yang diajukan adalah

\section{H2c $=$ Terdapat pengaruh country of brand origin terhadap perceived}

\subsubsection{Country of brand origin dan Brand reputation}

Negara yang dikaitkan dengan dimana produk atau merek diproduksi secara tradisional negara ini disebut negara asal. Negara asal dipahami sebagai efek yang muncul dalam persepsi konsumen yang dipengaruhi oleh lokasi dimana suatu produk dihasilkan. Lokasi atau negara tempat suatu produk dihasilkan akan mempengaruhi brand reputation kualitas produk tersebut. Country of brand origin tak jarang menjadi hal yang dipertimbangkan oleh seorang calon konsumen sebelum mereka melakukan tindakan pembelian. Persepsi country of brand origin yang baik akan menaikkan kepercayaan konsumen terhadap produk tersebut, sehingga dapat mempengaruhi brand reputation (Nuur \& Sunarti, 2018).

Penelitian yang dilakukan oleh (Filieri et al., 2018), menemukan bahwa terdapat pengaruh country of brand origin dengan brand reputation. Dengan demikian, mengikuti literatur ini kami berpendapat bahwa semakin tinggi country of brand origin, semakin tinggi brand reputation produk itu. Dengan demikian, hipotesis yang diajukan adalah:

\section{$\mathbf{H} 2 \mathrm{~d}=$ Terdapat pengaruh country of brand origin terhadap brand reputation}

\subsubsection{Brand loyalty dan Brand equity}

Brand loyalty dapat didefinisikan sebagai komitmen yang dipegang teguh untuk membeli kembali atau merendahkan kembali produk/layanan yang disukai secara konsisten di masa depan, sehingga menyebabkan pembelian merek yang sama secara berulang, terlepas dari pengaruh situasional dan upaya pemasaran yang memiliki berpotensi menyebabkan perilaku berpindah (Ha \& Park, 2012). Sementara brand equity adalah efek diferensial dari pengetahuan merek pada respons konsumen terhadap pemasaran merek. Brand equity juga mengacu pada nilai tambah yang diberikan oleh merek kepada produk (Nyadzayo, Matanda, \& Ewing, 2011). Pentingnya brand loyalty diakui dalam industri oleh para manajer dan juga oleh para peneliti. Ketika kita berbicara tentang anteseden dari brand loyalty, itu berarti bahwa konsumen bergerak dari fase yang berbeda untuk mencapai sikap dan kemudian ke tahap perilaku brand loyalty (Saleem, Rahman, \& Umar, 2015).

Preferensi konsumen untuk satu merek tertentu dalam hal perilaku dan sikap pembelian, membentuk brand loyalty. Brand loyalty dapat dibagi menjadi loyalitas perilaku, loyalitas emosional, loyalitas kognitif, dan loyalitas yang disengaja (Yang \& Wang, 2010). Jika perusahaan gagal untuk membedakan diri mereka pada tingkat di luar manfaat fungsional (berbasis produk), mereka tidak akan mampu mempertahankan brand loyalty. Sebagai contoh: konsumen akan memilih kosmetik dengan harga lebih murah, yang mengandung bahan aktif yang sama kecuali mereka merasa bahwa suatu merek menawarkan nilai lebih. Produsen kosmetik harus menyadari bahwa merek kosmetik memiliki potensi untuk terhubung dengan konsumen secara emosional (Panchal, Khan, \& Ramesh, 2012).

Penelitian yang dilakukan oleh (Buil, Martınez, \& Chernatony, 2013), menemukan adanya pengaruh brand loyalty dengan brand equity. Penelitian yang sama dilakukan oleh 
(Filieri et al., 2018), menemukan pengaruh brand loyalty dengan brand equity. Dengan demikian, mengikuti literatur ini kami berpendapat bahwa semakin tinggi brand loyalty, semakin tinggi brand equity produk itu. Dengan demikian, hipotesis yang diajukan adalah:

\section{H3 = Terdapat pengaruh brand loyalty terhadap brand equity}

\subsubsection{Brand awareness dan Brand equity}

Brand equity adalah seperangkat aset dan liabilitas merek yang dikaitkan dengan merek, nama, dan simbolnya yang menambah atau mengurangi nilai yang diberikan oleh suatu produk atau layanan kepada perusahaan dan konsumen perusahaan itu. Agar aset atau kewajiban mendasari brand equity, mereka harus dikaitkan dengan nama dan simbol merek (Panchal et al., 2012). Brand awareness memainkan peran penting dalam memilih di antara opsi terbaik yang tersedia yang dimiliki konsumen. Perusahaan berfokus pada mempromosikan produk mereka secara berkala sehingga merek diidentifikasi dan diingat oleh konsumen (Hassan et al., 2016). Membangun kesadaran jauh lebih mudah selama periode waktu yang lebih lama karena belajar bekerja lebih baik dengan pengulangan dan penguatan. Orang akan sering membeli merek yang akrab karena mereka merasa nyaman dengan yang akrab. Atau mungkin ada asumsi bahwa merek yang akrab mungkin dapat diandalkan, dalam bisnis untuk tinggal, dan kualitas yang masuk akal. Merek yang dikenal karenanya akan sering dipilih daripada merek yang tidak dikenal. Faktor kesadaran sangat penting dalam konteks di mana merek harus terlebih dahulu memasukkan pertimbangan yang ditetapkan - itu harus salah satu merek yang dievaluasi. Merek yang tidak dikenal biasanya memiliki sedikit peluang (Panchal et al., 2012). Menurut (Pouromid \& Iranzadeh, 2012) Brand awareness memiliki kepunyaan langsung terhadap brand equity. Brand awareness mengarah pada pembangunan brand equity dalam pola pikir konsumen (Huang \& Sarigöllü, 2012).

Penelitian yang dilakukan oleh (Buil et al., 2013), menemukan bahwa adanya pengaruh brand loyalty dengan brand equity. Penelitian yang sama dilakukan oleh (Filieri et al., 2018), menemukan bahwa terdapat pengaruh brand awareness dengan brand equity. Dengan demikian, mengikuti literatur ini kami berpendapat bahwa semakin tinggi brand awareness, semakin tinggi brand equity produk itu. Dengan demikian, hipotesis yang diajukan adalah:

\section{H4 = Terdapat pengaruh brand awareness terhadap brand equity}

\subsubsection{Preceived Quality dan Brand equity}

Definisi perceived quality dalam konteks layanan menunjukkan bahwa ini adalah hasil perbandingan yang dibuat konsumen antara harapannya tentang layanan dan persepsi tentang cara layanan telah dilakukan (Ha \& Park, 2012). Perceived quality juga merupakan sebuah konstruk seperti sikap yang memengaruhi perilaku pasca konsumsi konsumen. Perceived quality yang lebih tinggi mendorong perilaku yang lebih baik (Jang \& Ha, 2014). Brand equity yang baik menarik lebih banyak perhatian, minat, dan kontak dari konsumen potensial, serta meningkatkan kepuasan konsumen dan positif dari mulut ke mulut. Dengan demikian, distribusi melalui brand equity yang baik memberi sinyal bahwa suatu merek memiliki kualitas yang baik (Chitcharoen, Kanthawongs, Wathanasuksiri, \& Kanthawongs, 2013). Perceived quality tidak dapat selalu ditentukan secara objektif, sebagian karena itu adalah persepsi dan juga karena penilaian tentang apa yang penting bagi konsumen terlibat. Perceived quality didefinisikan relatif terhadap tujuan yang dimaksudkan dan serangkaian alternatif. Dalam penelitian yang dilakukan oleh (Panchal et al., 2012), menunjukkan perbedaan perceived quality untuk produk tidak bermerek dan bermerek.

Perceived quality adalah penilaian psikologis konsumen tentang kualitas produk berdasarkan persepsi mereka. Karakteristik obyektif dari suatu produk meliputi sinyal intrinsik 
dan ekstrinsik kualitas. Sinyal intrinsik mengarah pada perceived quality, sehingga manajer harus berusaha untuk mengurangi kesenjangan antara kualitas yang diharapkan dan kualitas yang diamati (Saleem et al., 2015). Penelitian yang dilakukan oleh (Sanyal \& Datta, 2011), menemukan bahwa terdapat pengaruh perceived quality dengan brand equity.

Penelitian yang dilakukan oleh (Buil et al., 2013), menemukan bahwa terdapat pengaruh perceived quality dengan brand equity. Penelitian yang sama dilakukan oleh (Filieri et al., 2018), menemukan bahwa terdapat pengaruh perceived quality dengan brand equity. Dengan demikian, mengikuti literatur ini kami berpendapat bahwa semakin tinggi perceived quality, semakin tinggi brand equity produk itu. Dengan demikian, hipotesis yang diajukan adalah:

\section{H5 = Terdapat pengaruh perceived quality terhadap brand equity}

\subsubsection{Brand reputation dan Brand equity}

Brand equity didefinisikan sebagai efek diferensial dari pengetahuan merek pada respons konsumen terhadap pemasaran suatu merek. Brand equity melibatkan elemen hubungan khusus yang menghubungkan konsumen dengan merek. Reputasi yang tinggi berarti lebih banyak konsumen, sebaliknya lebih sedikit konsumen yang tidak puas, akan menurunkan reputasi (C. Chen \& Myagmarsuren, 2011). Investasi dalam reputasi mengembangkan dukungan pemangku kepentingan dan meningkatkan kepercayaan konsumen terhadap penawaran yang diberikan perusahaan. Reputasi suatu perusahaan akan memberi tahu seberapa baik perusahaan memenuhi komitmennya dan memenuhi harapan berbagai pemangku kepentingan di masa lalu dan memprediksi perilaku di masa depan (Hsu, 2012). Merek yang diposisikan sebagai yang unggul dengan memberikan nilai unik kepada konsumen memperoleh brand reputation yang lebih besar dari para pesaingnya, yang mengarah ke hasil merek yang unggul. Dari perspektif teori sinyal, orang menggunakan pengalaman dan pengetahuan mereka tentang brand reputation sebagai sinyal karena mereka sering tidak dapat mengenal perusahaan dengan baik (Hur, Kim, \& Woo, 2013).

Brand reputation mengacu pada sikap konsumen bahwa merek itu baik dan dapat diandalkan dan menunjukkan bahwa reputasi positif mengungkapkan tingkat risiko yang rendah dan merangsang keputusan pembelian (Han, Nguyen, \& Lee, 2015). Oleh karena itu, brand reputation melibatkan persepsi konsumen terhadap citra publik, inovasi, kualitas produk dan layanan, dan komitmen terhadap kepuasan konsumen. Brand reputation dikaitkan dengan brand equity dan kredibilitas perusahaan, itu dipandang sebagai tanda kepercayaan. Namun, sulit untuk dibangun, tetapi mudah hilang. Ini mengharuskan perusahaan untuk tetap termotivasi untuk mempertahankan brand reputation yang baik setelah diciptakan (Zhang et al., 2011).

Penelitian yang dilakukan oleh (Buil et al., 2013), menemukan bahwa terdapat pengaruh brand reputation dengan brand equity. Penelitian juga dilakukan oleh (Qalati, Wenyuan, Kwabena, Erusalkina, \& Pervaiz, 2019), menemukan bahwa terdapat pengaruh brand reputation dengan brand equity. Penelitian yang dilakukan oleh (Filieri et al., 2018), menemukan bahwa terdapat pengaruh brand reputation dengan brand equity. Dengan demikian, mengikuti literatur ini kami berpendapat bahwa semakin tinggi brand reputation, semakin tinggi brand equity produk itu. Dengan demikian, hipotesis yang diajukan adalah:

\section{H6 $=$ Terdapat pengaruh brand reputation terhadap brand equity}

\subsubsection{Brand Equity dan Purchase intention}

Ketika istilah "brand equity" muncul pada tahun 1980, itu membuat pemasaran merek menjadi lebih populer dan mendapat perhatian tinggi bagi banyak organisasi di pasar. Menurut American marketing Association (AMA), merek adalah jumlah dari nama, simbol, dan desain 
yang membantu konsumen untuk mengidentifikasi produk atau layanan satu penjual, dan itu membuat perbedaan dengan penjual lainnya. Merek adalah penjelasan terhadap objek fisik, dan sangat abstrak yang ada pada suatu produk. Evaluasi brand equity dapat diukur dari sudut pandang produsen, distributor, dan konsumen (Chi, Yeh, \& Huang, 2019). Brand equity adalah aset tak berwujud yang muncul dari aktivitas pembangunan merek di masa lalu dan mencakup nilai tambah yang diberikan oleh merek ke produk (Christodoulides, Cadogan, \& Veloutsou, 2015). Menurut (Alexander \& Jaolis, 2019), niat dianggap terdiri dari faktor-faktor motivasi yang mengarah pada perilaku tertentu yang niatnya akan menunjukkan seberapa banyak yang telah dilakukan seseorang untuk melakukan perilaku. Dengan kata lain, jika seseorang memiliki niat yang tinggi untuk sesuatu, dia akan cenderung meningkatkan kinerjanya untuk mendapatkan apa yang dia inginkan pada awalnya.

Saat ini, ketika konsumen berpikir untuk membeli satu produk, mereka tidak hanya melihat nilai produk, tetapi juga nilai tambahnya. Misalnya, konsumen cenderung melihat brand equity yang dimiliki seperti: apakah sikap layanan penjual dan citra merek sangat baik atau tidak, apakah kepedulian penuh terhadap suatu merek menambah nilainya atau tidak, apakah kosmetik yang dibeli oleh konsumen wanita melukai kulit mereka atau tidak, apakah pembelian produk akan mengurangi risiko yang dirasakan konsumen atau tidak dan apakah ada hubungan konsumen yang baik antara penjual dan konsumen agar konsumen dapat menjaga hubungan yang baik dengan mereka, dan kemudian mempengaruhi keandalan, kepuasan, janji, dan loyalitas kepada perusahaan (C. . Chen, Chen, \& Lin, 2011). Tindakan yang diambil oleh perusahaan ritel untuk meningkatkan brand equity adalah melakukan pelatihan layanan konsumen untuk personel, tata letak toko, promosi, lokasi, harga, kualitas produk, bermacammacam produk, program loyalitas, dan keterlibatan masyarakat. Adanya tindakan tersebut, pada akhirnya akan membuat konsumen kemudian bereaksi dengan membangun purchase intention (Allaway, Huddleston, Whipple, \& Ellinger, 2011)).

Brand equity akan mempengaruhi niat pembelian konsumen, dan konsumen akan membeli produk merek dengan harga tinggi atau membeli produk merek secara terus menerus ketika suatu produk memiliki brand equity tinggi. Ini menunjukkan brand equity dan niat beli terkait positif (Chi et al., 2019). Penelitian yang dilakukan oleh (Moradi \& Zarei, 2011), menunjukkan bahwa brand equity mencakup banyak hal, karena pengalaman konsumen, perasaan dan apa yang mereka pelajari tentang merek dalam jangka panjang, relevan dengan konsep brand equity. Istilah ini adalah kata yang kita ketahui tentang brand equity berbasis konsumen dan itu adalah nilai tambah yang terhubung ke produk dalam benak, kata-kata, dan tindakan konsumen, sehingga terdapat pengaruh terhadap purchase intention.

Penelitian yang dilakukan oleh (Tharmi \& Senthilnathan, 2012), menemukan bahwa terdapat hubungan positif brand equity dengan purchase intention. Penelitian juga dilakukan oleh (Moreira, Fortes, \& Santiago, 2017), menunjukkan bahwa brand equity memiliki hubungan dengan purchase intention. Penelitian yang sama dilakukan oleh (Filieri et al., 2018), menemukan bahwa terdapat pengaruh brand equity dengan purchase intention. Dengan demikian, mengikuti literatur ini kami berpendapat bahwa semakin tinggi brand equity, semakin banyak konsumen memiliki purchase intention merek itu. Dengan demikian, hipotesis yang diajukan adalah:

H7 = Terdapat pengaruh brand equity terhadap purchase intention. 


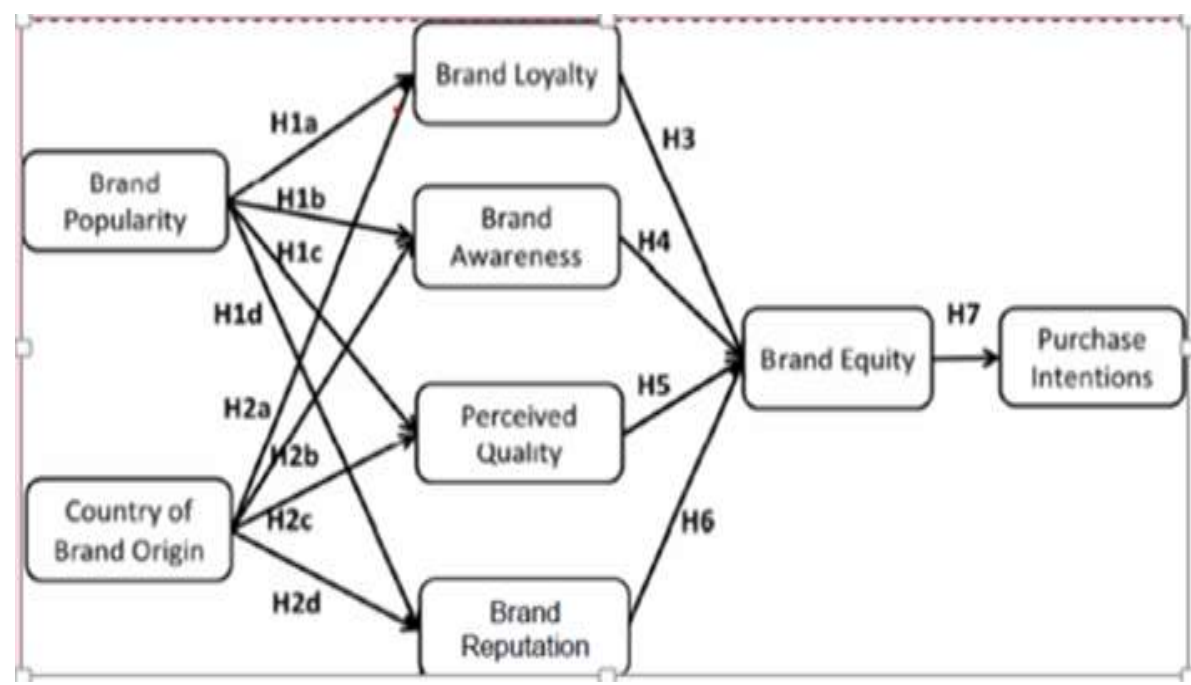

Gambar 2. Model Penelitian

\section{METODOLOGI PENELITIAN}

Berdasarkan paparan konsep diatas mengenai hubungan - hubungan antar variabel yang berasal dari penelitian sebelumnya, maka terbentuklah model penelitian seperti dihalaman berikutnya yang berasal dari (Filieri et al., 2019). Penelitian ini dianalisis secara kuantitatif melalui metode multivariat teknik Structural Equation Model (SEM) menggunakan analisis regresi partial (Partial Least Square/PLS) untuk menguji kelima hipotesis yang diajukan dalam penelitian ini. Masing-masing hipotesis akan dianalisis menggunakan software SmartPLS 3.0 untuk menguji hubungan antar variable.

Pendugaan parameter di dalam PLS meliputi 3 hal, yaitu (Ghozali, 2015, h. 19):

a. Weight estimate yang digunakan untuk menciptakan skor variabel laten.

b. Estimasi jalur (path estimate) yang menghubungkan antar variabel laten dan estimasi loading antara variabel laten dengan indikatornya.

c. Means dan lokasi parameter (nilai konstanta regresi, intersep) untuk indikator dan variabel laten.

d. Estimasi model: pada langkah ini, ada tiga skema pemilihan weighting dalam proses estimasi model, yaitu factor weighting scheme, centroid weighting scheme, dan path weighting scheme.

e. Evaluasi model meliputi evaluasi model pengukuran dan evaluasi model struktural.

f. Pengujian hipotesis dan interpretasi.

Untuk memperoleh ketiga estimasi ini, PLS menggunakan proses iterasi tiga tahap dan setiap tahap iterasi menghasilkan estimasi. Tahap pertama menghasilkan penduga bobot (weight estimate), tahap kedua menghasilkan estimasi untuk inner model dan outer model, dan tahap ketiga menghasilkan estimasi means dan lokasi (konstanta). Pada dua tahap pertama proses iterasi dilakukan dengan pendekatan deviasi (penyimpangan) dari nilai means (ratarata). Pada tahap ketiga, estimasi bisa didasarkan pada matriks data asli dan atau hasil penduga bobot dan koefisien jalur pada tahap kedua, tujuannya untuk menghitung dan lokasi parameter (Ghozali, 2015, h. 20). 


\section{HASIL PENELITIAN DAN PEMBAHASAN}

Variabel brand popularity memiliki 4 indikator yang menunjukkan perhitungan ratarata dari semua indikator 3,686. Ini berarti kecenderungan responden menjawab pertanyaan lebih cenderung setuju. Variabel country of brand origin memiliki 6 indikator yang menunjukkan perhitungan rata-rata rata-rata dari semua indikator 3,976, yang menunjukkan bahwa umumnya responden menjawab cukup setuju dalam kuesioner. Karakteristik yang sama ditunjukkan oleh brand loyalty memiliki 3 indikator yang mengatakan bahwa kecenderungan responden menunjukkan rata-rata 3,990, menggambarkan bahwa mereka kemungkinan besar menjawab cukup setuju. Selain itu, variabel brand awareness yang memiliki 4 indikator menunjukkan rata-rata 3,818, ini artinya kecenderungan responden menjawab cukup setuju dalam kuesioner. variabel perceived quality yang memiliki 6 indikator menunjukkan rata-rata 3,701 , ini artinya kecenderungan responden menjawab cukup setuju dalam kuesioner. Variabel brand reputation yang memiliki 6 indikator menunjukkan rata-rata 3,658, ini artinya kecenderungan responden menjawab setuju dalam kuesioner. Variabel brand equity yang memiliki 3 indikator menunjukkan rata-rata 3,426, ini artinya kecenderungan responden menjawab cukup setuju dalam kuesioner. Kemudian, karakteristik yang ditunjukkan oleh purchace intention memiliki rata-rata rata-rata dari 4 indikator 3,625, ini berarti kecenderungan responden menjawab pertanyaan lebih cenderung untuk cukup setuju. Seperti melihat angka standar deviasi, angka kisaran terletak pada 0,72 - 1,54, menunjukkan sejumlah besar standar deviasi yang berarti dispersi data jauh dari rata-rata sesuai dengan Tabel 2 di bawah ini.

Table 2. Statistik Deskriptif

\begin{tabular}{|c|c|c|c|c|c|c|}
\hline Indikator & No. & Mean & Median & Min & Max & Standar Deviasi \\
\hline BP1 & 1 & 3.714 & 4 & 1 & 5 & 1.17 \\
\hline BP2 & 2 & 3.678 & 4 & 1 & 5 & 1.26 \\
\hline BP3 & 3 & 3.697 & 4 & 1 & 5 & 1.29 \\
\hline BP4 & 4 & 3.656 & 4 & 1 & 5 & 1.32 \\
\hline COO1 & 5 & 4.322 & 4 & 3 & 5 & 0.72 \\
\hline COO2 & 6 & 3.725 & 4 & 1 & 5 & 1.37 \\
\hline COO3 & 7 & 3.719 & 4 & 1 & 5 & 1.41 \\
\hline COO4 & 8 & 3.803 & 4 & 1 & 5 & 1.41 \\
\hline COO5 & 9 & 3.958 & 4 & 2 & 5 & 0.99 \\
\hline COO6 & 10 & 4.331 & 4 & 3 & 5 & 0.73 \\
\hline BL1 & 11 & 3.997 & 4 & 1 & 5 & 1.30 \\
\hline BL2 & 12 & 3.989 & 5 & 1 & 5 & 1.35 \\
\hline BL3 & 13 & 3.983 & 4 & 2 & 5 & 0.89 \\
\hline BA1 & 14 & 3.828 & 4 & 1 & 5 & 1.46 \\
\hline BA2 & 15 & 3.689 & 4 & 1 & 5 & 1.48 \\
\hline BA3 & 16 & 3.900 & 4 & 2 & 5 & 0.97 \\
\hline BA4 & 17 & 3.856 & 4 & 2 & 5 & 0.98 \\
\hline PQ1 & 18 & 3.903 & 4 & 2 & 5 & 1.04 \\
\hline PQ2 & 19 & 3.897 & 4 & 2 & 5 & 1.07 \\
\hline PQ3 & 20 & 3.564 & 4 & 1 & 5 & 1.54 \\
\hline PQ4 & 21 & 3.775 & 4 & 1 & 5 & 1.44 \\
\hline PQ5 & 22 & 3.553 & 4 & 1 & 5 & 1.45 \\
\hline PQ6 & 23 & 3.514 & 4 & 1 & 5 & 1.45 \\
\hline BR1 & 24 & 3.947 & 4 & 1 & 5 & 1.20 \\
\hline BR2 & 25 & 3.819 & 4 & 1 & 5 & 1.28 \\
\hline BR3 & 26 & 3.417 & 4 & 1 & 5 & 1.27 \\
\hline BR4 & 27 & 3.475 & 4 & 1 & 5 & 1.34 \\
\hline BR5 & 28 & 3.406 & 4 & 1 & 5 & 1.25 \\
\hline BR6 & 29 & 3.886 & 4 & 2 & 5 & 0.98 \\
\hline & & & & & & \\
\hline
\end{tabular}




\begin{tabular}{|c|c|c|c|c|c|c|}
\hline Indikator & No. & Mean & Median & Min & Max & Standar Deviasi \\
\hline BE1 & 30 & 3.475 & 4 & 1 & 5 & 1.32 \\
\hline BE2 & 31 & 3.464 & 4 & 1 & 5 & 1.39 \\
\hline BE3 & 32 & 3.339 & 4 & 1 & 5 & 1.40 \\
\hline PI1 & 33 & 3.886 & 4 & 2 & 5 & 0.97 \\
\hline PI2 & 34 & 3.536 & 4 & 1 & 5 & 1.41 \\
\hline PI3 & 35 & 3.483 & 4 & 1 & 5 & 1.42 \\
\hline PI4 & 36 & 3.594 & 4 & 1 & 5 & 1.36 \\
\hline
\end{tabular}

Sumber: Data diolah (2020)

\subsection{Discriminant Validity Test}

Validitas diskriminan juga mendukung penghapusan delapan indikator dengan menunjukkan semua beban silang antara indikator dan variabel valid karena nilainya di atas 0,70 yang merupakan aturan praktis validitas diskriminan menggunakan cross loading. Ukuran validitas diskriminan konstruk yang secara teoritis tidak boleh saling terkait, sedangkan ukuran validitas konvergen konstruk yang secara teoritis harus terkait satu sama lain. Baik validitas konvergen maupun diskriminatif adalah bentuk validitas konstruk. Oleh karena itu, dengan terbukti bahwa semua indikator valid, dikatakan bahwa konstruk tersebut valid. Setelah semua indikator valid dan dibuktikan dengan validitas konvergen dan diskriminan, maka dapat dilakukan uji reliabilitas dan untuk uji inner model yang terdiri dari uji R-square dan signifikansi. Validitas diskriminan dengan beban silang ditunjukkan pada Tabel 3 berikut.

Tabel 3. Hasil Discriminant Validity

\begin{tabular}{|l|l|l|l|l|l|l|l|l|}
\hline & BP & COO & BL & BA & PQ & BR & BE & PI \\
\hline BP1 & 0.742 & & & & & & & \\
\hline BP2 & 0.821 & & & & & & & \\
\hline BP3 & 0.856 & & & & & & & \\
\hline BP4 & 0.805 & & & & & & & \\
\hline COO1 & & 0.862 & & & & & & \\
\hline COO2 & & 0.743 & & & & & & \\
\hline COO3 & & 0.951 & & & & & & \\
\hline COO5 & & 0.746 & & & & & & \\
\hline COO6 & & 0.868 & & & & & & \\
\hline BL1 & & & 0.759 & & & & & \\
\hline BL2 & & & 0.921 & & & & & \\
\hline BL3 & & & 0.806 & & & & & \\
\hline BA1 & & & & 0.889 & & & & \\
\hline BA2 & & & & 0.935 & & & & \\
\hline BA3 & & & & 0.790 & & & & \\
\hline BA4 & & & & 0.892 & & & & \\
\hline PQ1 & & & & & 0.850 & & & \\
\hline PQ2 & & & & & 0.836 & & & \\
\hline PQ5 & & & & & 0.881 & & & \\
\hline PQ6 & & & & & 0.878 & & & \\
\hline BR1 & & & & & & 0.732 & & \\
\hline BR2 & & & & & & 0.740 & & \\
\hline
\end{tabular}




\begin{tabular}{|l|l|l|l|l|l|l|l|l|}
\hline & BP & COO & BL & BA & PQ & BR & BE & PI \\
\hline BR3 & & & & & & 0.864 & & \\
\hline BR4 & & & & & & 0.755 & & \\
\hline BR5 & & & & & & 0.862 & & \\
\hline BE1 & & & & & & & 0.876 & \\
\hline BE2 & & & & & & & 0.913 & \\
\hline BE3 & & & & & & & 0.871 & \\
\hline PI1 & & & & & & & & 0.766 \\
\hline PI2 & & & & & & & & 0.893 \\
\hline PI3 & & & & & & & & 0.877 \\
\hline PI4 & & & & & & & & 0.762 \\
\hline
\end{tabular}

Uji Cronbach's Alpha dan Composite Reliability dalam Tabel 4 berikut mendukung semua variabel karena nilainya di atas 0,70 yang berarti bahwa semua variabel cukup andal untuk melakukan tes berikutnya yang merupakan inner model.

Tabel 4. Nilai Cronbach's Alpha dan Composite Reliability untuk aktual test

\begin{tabular}{|l|c|c|c|c|}
\hline Variable & $\begin{array}{l}\text { Cronbach's } \\
\text { Alpha }\end{array}$ & $\begin{array}{l}\text { Composite } \\
\text { Reliability }\end{array}$ & $\begin{array}{l}\text { Rule } \\
\text { Thumb }\end{array}$ & $\begin{array}{l}\text { Model } \\
\text { Evaluasi }\end{array}$ \\
\hline Brand popularity & 0.825 & 0.882 & & Reliabel \\
\hline Country of brand origin & 0.891 & 0.921 & & Reliabel \\
\hline Brand loyalty & 0.774 & 0.870 & \multirow{4}{*}{$>0.70$} & Reliabel \\
\cline { 1 - 3 } Brand awareness & 0.908 & 0.931 & Reliabel \\
\hline Perceive Quality & 0.884 & 0.920 & & Reliabel \\
\hline Brand reputation & 0.850 & 0.894 & & Reliabel \\
\hline Brand equity & 0.864 & 0.917 & & Reliabel \\
\hline Purchase intention & 0.844 & 0.896 & & Reliabel \\
\hline
\end{tabular}

Sumber: Data diolah (2020)

\subsection{Goodness of fit}

Kriteria Goodnes of fit dalam PLS dikembangkan oleh Tenenhaus et al., (2004) dengan sebutan GoF Index. Index ini dikembangkan untuk mengevaluasi model pengukuran dan model struktural dan disamping itu menyediakan pengukuran sederhana untuk keseluruhan dari prediksi model. Berikut rumus GoF Index, yaitu: $\mathbf{G o F}=\sqrt{ }\left((\mathbf{C o m})^{-} \mathbf{x}\left(\mathbf{R}^{\mathbf{2}}\right)^{-}\right)$. Dimana, $(\mathrm{Com})^{-}$ $=$ average communality; $\left(\mathrm{R}^{\wedge} 2\right)^{-}=$average R-Square. Kategori GoF adalah: GoF small = 0.10; GoF medium $=0.25$; dan GoF large $=0.36$. Pada penelitian ini didapat nilai GoF sebesar 0.30, jadi dapat dikatakan bahwa kriteria Goodnes of fit pada penelitian ini masuk dalam kategori medium dan layak untuk pengukuran hipotesis, dimana perhitungan GoF sebagai berikut: GoF $=\sqrt{ }(0.71 \times 0.13=0.30$.

\subsection{Hipotesis}

Hipotesis yang telah diberikan harus diukur signifikansinya. Ini dapat diperoleh dengan melihat T-statistik $>1,96$ dan P-nilai $<0,05$ karena penelitian ini menggunakan tingkat kepercayaan 95\%. Berikut adalah tabel hasil pengujian hipotesis. Tabel 5 hasil hipotesis pengaruh langsung menunjukkan ada tiga belas hipotesis dalam tabel efek langsung. 
Tabel 5. Uji Hipotesis Pengaruh Langsung

\begin{tabular}{|l|c|c|c|c|}
\hline \multicolumn{1}{|c|}{ Hipotesa } & $\begin{array}{c}\text { Original } \\
\text { Sampel }\end{array}$ & T-statistic & $\begin{array}{c}\text { Sig P- } \\
\text { value }\end{array}$ & $\begin{array}{c}\text { Analisa } \\
\text { Hipotesa }\end{array}$ \\
\hline $\begin{array}{l}\text { H1a = Terdapat pengaruh brand } \\
\text { popularity terhadap brand loyalty }\end{array}$ & -0.024 & 0.472 & $\mathbf{0 . 6 3 7}$ & Hipotesa ditolak \\
\hline $\begin{array}{l}\text { H1b = Terdapat pengaruh brand } \\
\text { popularity terhadap brand awareness }\end{array}$ & 0.869 & 3.563 & $\mathbf{0 . 0 0 2}$ & Hipotesa diterima \\
\hline $\begin{array}{l}\text { H1c = Terdapat pengaruh brand } \\
\text { popularity terhadap perceived quality }\end{array}$ & 0.192 & 2.502 & $\mathbf{0 . 0 0 9}$ & Hipotesa diterima \\
\hline $\begin{array}{l}\text { H1d = Terdapat pengaruh brand } \\
\text { popularity terhadap brand reputation }\end{array}$ & 0.583 & 16.242 & $\mathbf{0 . 0 0 0}$ & Hipotesa diterima \\
\hline $\begin{array}{l}\text { H2a = Terdapat pengaruh country of } \\
\text { brand } \text { origin terhadap brand loyalty }\end{array}$ & 0.222 & 3.608 & $\mathbf{0 . 0 0 0}$ & Hipotesa diterima \\
\hline $\begin{array}{l}\text { H2b = Terdapat pengaruh country of } \\
\text { origin terhadap brand awareness }\end{array}$ & 0.861 & 3.406 & $\mathbf{0 . 0 0 2}$ & Hipotesa diterima \\
\hline $\begin{array}{l}\text { H2c = Terdapat pengaruh country of } \\
\text { brand } \text { origin terhadap perceived } \\
\text { quality }\end{array}$ & 0.148 & 2.697 & $\mathbf{0 . 0 0 7}$ & Hipotesa diterima \\
\hline $\begin{array}{l}\text { H2d = Terdapat pengaruh country of } \\
\text { origin terhadap brand reputation }\end{array}$ & 0.037 & 0.810 & $\mathbf{0 . 4 1 8}$ & Hipotesa ditolak \\
\hline $\begin{array}{l}\text { H3 = Terdapat pengaruh brand } \\
\text { loyalty terhadap brand equity }\end{array}$ & 0.181 & 2.769 & $\mathbf{0 . 0 0 8}$ & Hipotesa diterima \\
\hline $\begin{array}{l}\text { H4 = Terdapat pengaruh brand } \\
\text { awareness terhadap brand equity }\end{array}$ & 0.066 & 1.321 & $\mathbf{0 . 1 8 7}$ & Hipotesa ditolak \\
\hline $\begin{array}{l}\text { H5 = Terdapat pengaruh perceived } \\
\text { quality terhadap brand equity }\end{array}$ & -0.058 & 1.238 & $\mathbf{0 . 2 1 6}$ & Hipotesa ditolak \\
\hline $\begin{array}{l}\text { H6 = Terdapat pengaruh brand } \\
\text { reputation terhadap brand equity }\end{array}$ & 0.369 & 8.089 & $\mathbf{0 . 0 0 0}$ & Hipotesa diterima \\
\hline $\begin{array}{l}\text { H7 = Terdapat pengaruh brand equity } \\
\text { terhadap purchase intention }\end{array}$ & 0.453 & 9.308 & $\mathbf{0 . 0 0 0}$ & Hipotesa diterima \\
\hline Sumber: Data diolah (2020)
\end{tabular}

Sumber: Data diolah (2020)

Penelitian ini merupakan modifikasi dari penelitian sebelumnya dari Filieri et al., (2018). Mereka melakukan penelitian tentang smartphone yang berlokasi di China. Sedangkan pada penelitian ini menggunakan objek penelitian yang berasal dari populasi pengguna produk etude house Indonesia.

\section{KESIMPULAN}

\subsection{Kesimpulan}

Dari analisis data menggunakan SmartPLS 3.0, ada sembilan hipotesis yang didukung dan empat hipotesis tidak didukung dalam pengujian hipotesis. Penelitian ini mendukung bahwa terdapat pengaruh brand popularity terhadap brand awareness, terdapat pengaruh brand popularity terhadap perceived quality, terdapat pengaruh brand popularity terhadap brand reputation, terdapat pengaruh country of brand origin terhadap brand loyalty, terdapat pengaruh country of brand origin terhadap brand awareness, terdapat pengaruh country of brand origin terhadap perceived quality, terdapat pengaruh brand loyalty terhadap brand equity, terdapat pengaruh brand reputation terhadap brand equity. Selain itu, brand equity juga berdampak pada purchase intention. Namun, dalam penelitian ini hubungan brand popularity terhadap brand loyalty, pengaruh country of brand origin terhadap brand reputation, pengaruh brand awareness terhadap brand equity dan pengaruh perceived quality terhadap brand equity tidak didukung dalam pengujian hipotesis. Berikut ini adalah hasil dari hipotesis. 
H1a: Tidak ada pengaruh brand popularity terhadap brand loyalty.

Mereka lebih memilih pada produk-produk yang sesuai dengan tren globalisasi dan gaya hidup dinamis di masa sekarang, sehingga mereka tidak memiliki loyalitas pada merek tertentu. Selain itu, ada kemungkinan kesalahan dalam tanggapan responden karena kuesioner sebagai metode pengumpulan data. Responden mungkin memiliki kemungkinan untuk tidak menjawab dengan jujur atau salah menafsirkan pertanyaan. Oleh karena itu, kemungkinankemungkinan itu menghasilkan hipotesis yang tidak didukung.

H1b: Ada pengaruh brand popularity terhadap brand awareness.

H1c: Ada pengaruh brand popularity terhadap perceived quality.

H1d: Ada pengaruh brand popularity terhadap brand reputation.

H2a: Ada pengaruh country of brand origin terhadap brand loyalty.

H2b: Ada pengaruh country of brand origin terhadap brand awareness.

H2c: Ada pengaruh country of brand origin terhadap perceived quality.

H2d: Tidak ada pengaruh country of brand origin terhadap brand reputation.

Mereka tidak melihat brand reputation dari produk yang mereka beli, mereka hanya melihat darimana asal produk tersebut, karena hal tersebut bukanlah hal yang penting. Terdapat efek tidak langsung dari country of brand origin terhadap brand equity karena peran mediasi brand reputation di antara mereka. Korea Selatan memiliki country of brand origin yang kuat pada produk perawatan kulit dan wajah, namun sayangnya pada merek Etude House peran brand reputation tidak terlalu besar untuk menjadi mediasi dikarenakan pernah terjadi isu yang sempat ramai mengenai salah satu dari produk Etude House mengandug logam berat yang berlebih setelah ditemukan oleh Otoritas Keamanan Obat dan Makaan Korea, menyebabkan brand reputation Etude House menurun Selain itu, ada kemungkinan kesalahan dalam tanggapan responden karena kuesioner sebagai metode pengumpulan data. Responden mungkin memiliki kemungkinan untuk tidak menjawab dengan jujur atau salah menafsirkan pertanyaan. Oleh karena itu, kemungkinan-kemungkinan itu menghasilkan hipotesis yang tidak didukung.

H3: Ada pengaruh brand loyalty terhadap brand equity. H4: Tidak ada pengaruh brand awareness terhadap brand equity.

Remaja memiliki perilaku yang mengutamakan gaya hidup, karena mereka selalu mencoba hal-hal baru bahkan mereka tidak mengenal merek dari produk yang mereka beli. Selain itu, ada kemungkinan kesalahan dalam tanggapan responden karena kuesioner sebagai metode pengumpulan data. Responden mungkin memiliki kemungkinan untuk tidak menjawab dengan jujur atau salah menafsirkan pertanyaan. Oleh karena itu, kemungkinan-kemungkinan itu menghasilkan hipotesis yang tidak didukung.

H5: Tidak ada pengaruh perceived quality terhadap brand equity.

Remaja memiliki perilaku yang selalu mencoba hal-hal baru sehingga mereka tidak memiliki persepsi yang objektif pada suatu produk. Karakteristik obyektif dari suatu produk meliputi sinyal intrinsik dan ekstrinsik kualitas. Sinyal intrinsik mengarah pada persepsi kualitas, sehingga manajer harus berusaha untuk mengurangi kesenjangan antara kualitas yang diharapkan dan kualitas yang diamati (Saleem et al., 2015). Dengan adanya isu mengenai kandungan logam yang berlebih pada salah satu prodak Etude House menyebabkan pembeli menilai rendah mengenai perceived quality. Selain itu, ada kemungkinan kesalahan dalam tanggapan responden karena kuesioner sebagai metode pengumpulan data. Responden 
mungkin memiliki kemungkinan untuk tidak menjawab dengan jujur atau salah menafsirkan pertanyaan. Oleh karena itu, kemungkinan-kemungkinan itu menghasilkan hipotesis yang tidak didukung.

\section{H6: Ada pengaruh brand reputation terhadap brand equity. H7: Ada pengaruh brand equity terhadap purchase intention.}

\subsection{Implikasi Teoritis}

Dari hasil penelitian ini, implikasi teoretis yang dapat dideskripsikan adalah brand equity dan purchase intention. Penelitian ini adalah penelitian modifikasi konseptual dari penelitian sebelumnya yang dilakukan oleh (Filieri et al., 2018). Hasil yang diperoleh tidak sama dengan penelitian sebelumnya, dalam penelitian ini tidak ditemukan pengaruh brand popularity terhadap brand loyalty. Kemudian juga tidak ditemukan bahwa country of brand origin memiliki pengaruh terhadap brand reputation.

Penelitian ini juga tidak ditemukan bahwa brand awareness dan perceived quality memiliki pengaruh terhadap brand equity. Hal ini disebabkan adanya modifikasi dari penelitian sebelumnya, yaitu perbedaan objek penelitian, jika pada sebelumnya dilakukan pada objek Smartphone, pada penelitian ini dilakukan penelitian pada merek kosmetik. Namun, terdapat beberapa kesamaan dari penelitian ini bahwa terdapat pengaruh brand popularity terhadap brand awareness, terdapat pengaruh brand popularity terhadap perceived quality, terdapat pengaruh brand popularity terhadap brand reputation, terdapat pengaruh country of brand origin terhadap brand loyalty, terdapat pengaruh country of brand origin terhadap brand awareness, terdapat pengaruh country of brand origin terhadap perceived quality, terdapat pengaruh brand loyalty terhadap brand equity, terdapat pengaruh brand reputation terhadap brand equity. Selain itu, brand equity juga berdampak pada purchase intention. Purchase intention mengarah pada kesetiaan seseorang terhadap suatu merek dengan pembelian berulang sebagai tindakan loyalitas.

\subsection{Implikasi Manajerial}

Implikasi manajerial yang dapat diberikan dari penelitian ini adalah strategi pemasaran yang dapat diterapkan pada strategi global marketing, terutama dalam produk merek internasional. Studi literatur dan sebelumnya masih sangat minim dalam membahas brand popularity dan country of brand origin. Seharusnya brand popularity dan country of brand origin serta hubungannya dengan variabel dalam penelitian ini dapat digunakan di seluruh negara melalui membangun merek yang kuat yang akan menghasilkan posisi tinggi di benak konsumen. Meninjau dari hasil kuesioner Karakteristik sebuah brand mencerminkan fenomena brand equity dengan terjadinya purchase intention . Juga, jika mereka melakukan pembelian berulang, itu menunjukkan loyalitas kepada merek.

Oleh karena itu, penelitian ini dapat berkontribusi sebagai dasar untuk studi praktis pemasaran global dan strategi branding. Sebaliknya, penelitian ini memberikan implikasi manajerial terhadap brand popularity dan kebijakan tentang distribusi country of brand origin. Dengan meningkatnya kesadaran publik tentang brand popularity dan country of brand origin, , menyebabkan masyarakat menjadi semakin rentan terhadap nilai yang dirasakan dengan memiliki beberapa country of brand origin di antara kelompok rekan dan kehidupan sosial mereka. Mereka cenderung bersedia membayar dengan harga premium untuk membeli barangbarang country of brand origin. Negara yang memiliki citra positif serta baik, dapat membuat kepercayaan terhadap produk yang positif juga.. Selain itu, dapat menggunakan aktor K-Pop atau K-Drama sebagai duta merek untuk mempromosikan produk juga dapat menjadi cara untuk menciptakan citra negara yang baik. 


\subsection{Keterbatasan Penelitian dan Saran Penelitian Selanjutnya}

Ada beberapa batasan dari penelitian ini adalah data yang dikumpulkan didasarkan pada kejujuran responden dalam menjawab pertanyaan kuesioner dan sesuai dengan konteks Indonesia. Data yang dikumpulkan berasal dari responden atau sampel yang berasal dari wilayah cakupan Jakarta, Bogor, Tangerang, Bekasi, Depok dan wilayah yang terdekat. Untuk penelitian selanjutnya, ada beberapa rekomendasi yang diberikan adalah: Menggunakan lebih banyak responden dengan lokasi geografis yang lebih luas dan dapat menggunakan penelitian longitudinal untuk mendapatkan hasil yang lebih akurat karena geografis yang berbeda akan mengandung karakteristik yang berbeda dan semakin lama waktu dapat membantu untuk menganalisis lebih dalam juga. Penelitian di masa depan dapat menerapkan teori ini untuk membandingkan dengan produk lokal sehingga peneliti dapat mengetahui karakteristik suatu produk yang akan membuat konsumen menginduksi brand equity terhadap purchase intention. Perlu menggunakan produk lain, sehingga dapat ditemukan hasil yang lebih baik dari penelitian sebelumnya.

\section{DAFTAR REFERENSI}

Alexander, R., \& Jaolis, F. (2019). Analisa Pengaruh Location Influence, Physica Influence, Price Importance dan Corporate Reputation Terhadap Residential Purchase intention: Studi Kasus De Victory Regency Surabaya. Jurnal Strategi Pemasaran, 6(1).

Allaway, A. W., Huddleston, P., Whipple, J., \& Ellinger, A. E. (2011). Customer-based Brand equity, Equiy Drivers, and Customer Loyalty In The Supermarket Industry. Journal of Product \& Brand Management, 20(3), 190-204.

Bruwer, J., \& Buller, C. (2013). Product Involvement, Brand loyalty, and Country of brand origin Brand Preferences of Japanese Wine Consumers. Journal of Wine Research2, 24(1), 38-58.

Bruwer, J., Buller, C., Saliba, A. J., \& Li, E. (2014). Country-of-origin (COO) Brand loyalty and Related Consumer Behaviour in The Japanese Wine Market. International Journal of Wine, 26(2), 97-119.

Buil, I., Martınez, E., \& Chernatony, L. De. (2013). The Influence of Brand equity on Consumer Responses. Journal of Consumer Marketing, 3(1), 62-74.

Chang, W. Y., \& Chang, I. Y. (2014). The influences of humorous advertising on brand popularity and advertising effects in the tourism industry. Sustainability (Switzerland), 6(12), 9205-9217. https://doi.org/10.3390/su6129205

Chen, C. ., Chen, T. ., \& Lin, Y. . (2011). Statistical Analysis For Consumers ' Intentions of Purchasing Cosmetics. African Journal of Business Management, 5(29), 11630-11635.

Chen, C., \& Myagmarsuren, O. (2011). Brand equity, Relationship Quality, Relationship Value, and Customer Loyalty: Evidence From The Telecommunications Services. Total Quality Management2, 22(9), 957-974.

Chi, H. K., Yeh, H. R., \& Huang, M. W. (2019). The Influences of Advertising Endorser, Brand Image, Brand equity, Price Promotion, on Purchase intention- The Mediating Effect of Advertising Endorser. Journal of Global Business Management, 5(1).

Chitcharoen, C., Kanthawongs, P., Wathanasuksiri, K., \& Kanthawongs, P. (2013). A Model to Investigate the Influence of Channel, Perceived Web Quality, Brand awareness, Perceived quality on After-Sales Service of the All-In-One Office Products. Procedia Social and Behavioral Sciences, 88, 8-12. 
Christodoulides, G., Cadogan, J. W., \& Veloutsou, C. (2015). Consumer-based Brand equity Measurement: Lessons Learned From an International Study. International Marketing Review, 32(3/4), 307-328.

Costa, C., Carneiro, J., \& Goldszmidt, R. (2016). A Contingent Approach to Country of brand origin Effects on Foreign Products Evaluation: Interaction of Facets of Country Image With Product Classes. International Business Review, 1-10.

Dessylistya. (2018). Sempat Ramai, Ini 8 Kosmetik Korea Selatan yang Ditarik dari Peredaran.

Devita, E. M., \& Agustini, M. Y. D. H. (2019). Country of brand origin and Brand Image on Purchase Decision of South Korean Cosmetic Etude House. Journal of Management and Business Environment (JMBE), 1(1), 55-70. https://doi.org/10.24167/JMBE.V1I1.2115

Dinata, J. S., Kumadji, S., \& Hidayat, K. (2015). Country of brand origin dan Pengaruhnya Terhadap Persepsi Kualitasnya dan Minat Beli (Survei pada Calon Konsumen yang Berminat Membeli iPad di Indonesia). Jurnal Administrasi Bisnis (JAB), 25(1), 1-8.

Ekarina. (2019). Tren Perawatan Kecantikan Naik, Industri Kosmetik Dipatok Tumbuh 9\%.

Eliasari, P. R. A., \& Sukaatmadja, I. P. G. (2017). Pengaruh Brand awareness Terhadap Purchase intention Dimediasi oleh Perceived quality \& Brand Loyality. E-Jurnal Manajemen Unud, 6(12), 6620-6650.

Erdogmus, I. E., \& Cicek, M. (2012). The Impact of Social Media Marketing on Brand loyalty. Procedia-Social and Behavioral Sciense, 58, 1353-1360.

Fan, X., Chang, E.-C., Zhang, M., \& Zhang, Y. (2013). The Influence of Negative Information from a Co-brand: The Moderating Roles of Involvement and Brand popularity. International Review of Management and Businesss Research, 2(2), 302-312.

Farhat, R., \& Mustafa, B. (2011). Importance of Brand Personality To Customer Loyalty : A Conceptual Study, 1, 4-11.

Filieri, R., Lin, Z., D’Antone, S., \& Chatzopoulou, E. (2018). A cultural approach to brand equity: the role of brand mianzi and brand popularity in China. Journal of Brand Management, 26(4), 376-394. https://doi.org/10.1057/s41262-018-0137-x

Gisbey, P. J. C. . (2016). Brand awareness and Brand popularity: A Malaysian Perspective. The International Journal Of Business \& Management, 4(7), 184-197.

Ha, H., \& Park, K. (2012). Effects of Perceived quality and Satisfaction on Brand loyalty in China: The Moderating Effect of Customer Orientation. African Journal of Business Management, 6(22), 6745-6753.

Han, S. H., Nguyen, B., \& Lee, T. J. (2015). Consumer-based chain restaurant brand equity, brand reputation, and brand trust. International Journal of Hospitality Management, 50, 84-93. https://doi.org/10.1016/j.ijhm.2015.06.010

Hassan, W., Shabbir, R., Yaqub, R. M. S., \& Imran, S. (2016). Effect of Brand popularity on Customer Pre-Purchase Dissonance, Customer Satisfaction and Brand Trust: A Study of Household Appliances Industry in Pakistan. Jurnal NUST Business School.

Hsu, K. (2012). The Advertising Effects of Corporate Social Responsibility on Corporate Reputation and Brand equity: Evidence from the Life Insurance Industry in Taiwan. Journal of Business Ethics, 109, 189-201.

Huang, R., \& Sarigöllü, E. (2012). How brand awareness relates to market outcome, brand equity, and the marketing mix. Journal of Business Research, 65(1), 92-99. https://doi.org/10.1016/j.jbusres.2011.02.003 
Hur, W., Kim, H., \& Woo, J. (2013). How CSR Leads to Corporate Brand equity : Mediating Mechanisms of Corporate Brand Credibility and Reputation. Journal of Business Ethics, 125(1), 1-12.

Jang, S., \& Ha, J. (2014). Do Loyal Customers Perceive the Quality of Restaurant Attributes Differently ?: A Study of Korean Restaurant Customers. Journal of Foodservice Business Research, 17, 257-266.

Jin, D. Y., \& Yoon, T. J. (2017). The Korean Wave: Retrospect and prospect: Introduction. International Journal of Communication, 11, 2241-2249.

Kershaw, S., Newton, J. T., \& Williams, D. M. (2008). The influence of tooth colour on the perceptions of personal characteristics among female dental patients: Comparisons of unmodified, decayed and "whitened" teeth. British Dental Journal, 204(5), 1-7. https://doi.org/10.1038/bdj.2008.134

Kim, J.-H., \& Min, D. (2016). Consumers' Response to an Advertisement Using Brand popularity in a Foreign Market. Japanese Psychological Research, 58(4), 342-354.

Kim, J. H., \& Min, D. (2014). The Effects of Brand popularity As An Advertising Cue on Perceived quality In The Context of Internet Shopping. Japanese Psychological Research, 56(4), 309-319.

Kim, M., Moon, S., \& Iacobucci, D. (2019). The Influence of Global Brand Distribution on Brand popularity on Social Media. Journal of International Marketing, 27(4), 22-38.

Lee, Y. (2017). The Effects of Self-Construal on Product Popularity. Journal of Marketing Management, 5(2), 15-21. https://doi.org/10.15640/jmm.v5n2a2

Liao, S. H., Wu, C. C., Widowati, R., \& Chen, M. Y. (2012). Relationships between brand awareness and daring word-of-mouth: An example of daring gaming community. International Journal of Web Based Communities, 8(2), 177-195. https://doi.org/10.1504/IJWBC.2012.046259

Luan, J., Shan, W., Wang, Y., \& Xiao, J. (2019). How easy-to-process information influences consumers over time: Daring review vs. brand popularity. Computers in Human Behavior, 97(February 2018), 193-201. https://doi.org/10.1016/j.chb.2019.03.028

Magnini, V. P., Karande, K., Singal, M., \& Kim, D. (2013). The effect of brand popularity statements on consumers ' purchase intentions: The role of instrumental attitudes toward the act $\Xi$. International Journal of Hospitality Management, 34, 160-168.

Moradi, H., \& Zarei, A. (2011). The Impact of Brand equity on Purchase intention and Brand Preference-the Moderating Effects of Country of brand origin Image. Australian Journal of Basic and Applied Sciences, 5(3), 539-545.

Moreira, A. C., Fortes, N., \& Santiago, R. (2017). Influence of Sensory Stimuli on Brand Experience, Brand equity and Purchase intention. Journal of Business Economics and Management, 18(1), 68-83.

Nuur, F., \& Sunarti, F. (2018). Pengaruh Country of brand origin Terhadap Citra Merek dan Dampaknya Pada Keputusan Pembelian. Jurnal Administrasi Bisnis (JAB)|Vol, 54(1), 111-119. Retrieved from www.statista.com

Nyadzayo, M. W., Matanda, M. J., \& Ewing, M. T. (2011). Brand Relationships and Brand equity in Franchising. Industrial Marketing Management, 40(7), 1103-1115. 
Panchal, S. K., Khan, B. M., \& Ramesh, S. (2012). Importance of Brand loyalty, Brand awareness and Perceived quality Paramaters in Building Brand equity in The Indian Pharmaceutical Industy. Journal of Medical Marketing, 12(2), 81-92.

Pouromid, B., \& Iranzadeh, S. (2012). The evaluation of the factors affects on the brand equity of pars khazar household appliances based on the vision of female consumers. Middle East Journal of Scientific Research, 12(8), 1050-1055. https://doi.org/10.5829/idosi.mejsr.2012.12.8.1796

Pumice. (2014). Etude House, Brand Kosmetik Dari Korea yang Booming di Tanah Air.

Qalati, S. A., Wenyuan, L., Kwabena, G. Y., Erusalkina, D., \& Pervaiz, S. (2019). Influence of Brand equity on Brand Performance: Role of Brand reputation and Social Media. International Journal of Research and Review, 6(9), 304-317.

Saleem, S., Rahman, S. U., \& Umar, R. M. (2015). Measuring Customer Based Beverage Brand equity: Investigating the Relationship between Perceived quality, Brand awareness, Brand Image, and Brand loyalty. International Journal of Marketing Studies, 7(1), 6677.

Sanyal, S. N., \& Datta, S. K. (2011). The Eeffect of Perceived quality on Brand equity: an Empirical Study on Generic Drugs. Asia Pacific Journal of Marketing and Logistic, 23(5), 604-625.

Severi, E., \& Ling, K. C. (2013). The mediating effects of brand association, brand loyalty, brand image and perceived quality on brand equity. Asian Social Science, 9(3), 125-137. https://doi.org/10.5539/ass.v9n3p125

Srihartati, E., \& Abdillah, Y. (2018). Pengaruh Korean Wave dan Country of brand origin Terhadap Brand awareness dan Brand Image Kosmetik Korea (Survei Pada Mahasiswa S1 Fakultas Ilmu Administrasi Universitas Brawijaya Konsumen Produk Kosmetik Etude House). Jurnal Administrasi Bisnis (JAB), 65(1), 36-45.

Tenenhaus, M., Amato, S., \& Vinzi, V. E. (2004). A global Goodness - of - Fit index for PLS structural. Proceeding of the XLII SIS Scientific Meeting, Contribute(Padova), 739-742.

Tharmi, U., \& Senthilnathan, S. (2012). The Relationship of Brand equity To Purchase intention. IUP Journal of Marketing Management, 1-20.

Tsou, H.-T., Liu, F.-H., \& Hsu, H.-Y. (2015). The Effects of Reputation and Relative Low Price on Purchase intention : Service Quality as a Mediated Moderator. Web Journal of Chinese Management Review, 18(3), 1-16.

Valdo, J., \& Subagio, H. (2017). Analisa pengaruh brand equity terhadap purchase intention konsumen pada produk pc tablet apple ipad di Surabaya. Universitas Kristen Petra, 4(2), $1-8$.

Wang, J., Wu, J. C., \& Fu, H. (2010). The Effect of Service Quality on Perceived Value, Brand reputation and Loyalty: a Study on Traveling Industry. Journal of Information \& Optimization Science, 31(3), 659-677.

Yang, D., \& Wang, X. (2010). The Effects of 2-tier Store Brands' Perceived quality, Perceived Value, Brand Knowledge, and Attitude on Store Loyalty. Frontiers of Literary Studies in China, 4(1), 1-28. https://doi.org/10.1007/s11782-010-0001-7

Zhang, Y., Fang, Y., Wei, K., Ramsey, E., Mccole, P., \& Chen, H. (2011). Repurchase intention in B2C e-commerce - A Relationship Quality Perspective. Information \& Management, 48(6), 192-200. 